\title{
Purchase Price Allocation
}

\author{
Bang Christensen, Tinus; Knudsen, Hans Jørgen; Plenborg, Thomas
}

Document Version

Final published version

Publication date:

2009

License

CC BY-NC-ND

Citation for published version (APA):

Bang Christensen, T., Knudsen, H. J., \& Plenborg, T. (2009). Purchase Price Allocation. Department of Accounting and Auditing, Copenhagen Business School.

Link to publication in CBS Research Portal

\section{General rights}

Copyright and moral rights for the publications made accessible in the public portal are retained by the authors and/or other copyright owners and it is a condition of accessing publications that users recognise and abide by the legal requirements associated with these rights.

\section{Take down policy}

If you believe that this document breaches copyright please contact us (research.lib@cbs.dk) providing details, and we will remove access to the work immediately and investigate your claim. 


\section{Purchase Price Allocation - en introduktion}

by

Partner Tinus Bang Christensen, Deloitte Partner Hans Jørgen Knudsen, Ernst \& Young Professor Thomas Plenborg, CBS

INSTITUT FOR REGNSKAB OG REVISION, Handelshøjskolen i København Solbjerg Plads 3, C.4., 2000 Frederiksberg

TIf.: 38152320 Fax: 38152321

DEPARTMENT OF ACCOUNTING AND AUDITING, Copenhagen Business School Solbjerg Plads 3, C.4., DK-2000 Frederiksberg

Phone: +45 38152320 Fax: +4538152321

uk.cbs.dk/forskning_viden/institutter_centre/institutter/rr 


\section{Indledning}

Siden 2004 har danske virksomheder, der aflægger regnskab efter internationale regnskabsstandarder, skullet foretage allokering af købesum, også kaldet Purchase Price Allocation (PPA) ved virksomhedsovertagelser. PPA er reguleret i IFRS 3 Business Combinations og betyder i praksis, at man ikke kan allokere forskellen mellem købesummen og den bogførte værdi af aktiverne til goodwill. I stedet er det påkrævet at indregne alle overtagne aktiver til dagsværdi, herunder også aktiver der ikke tidligere har været identificeret i balancen. Det vil typisk være immaterielle aktiver såsom kundelister, varemærker og teknologi.

Formålet med denne artikel er at udbrede viden om PPA, herunder redegøre for hvordan en købesumsallokering bliver foretaget i praksis. Der fokuseres i artiklen på følgende områder:

- Introduktion til IFRS 3

- Identifikation af immaterielle aktiver ifølge IFRS 3

- Værdiansættelse af immaterielle aktiver ifølge IFRS 3

- Regnskabsmæssige konsekvenser ved PPA

- $\quad$ Ekstern rapportering

Denne artikel er den første af to artikler om PPA. Nærværende artikel er en introduktion til PPA, da dette emne stadig er relativt nyt for en lang række danske virksomheder. Næste artikel går mere i dybden med fordelene ved at lave købesumsallokering tidligt i opkøbsprocessen - kaldet pre-deal PPA eller indikativ PPA. Der er mange fordele for virksomheder, der formår at benytte PPA aktivt som strategisk værktøj, og dermed bevæger sig væk fra den rent lovmæssige opfyldelse af regnskabsreglerne. Det er vores oplevelse, at meget få virksomheder udnytter denne mulighed i praksis.

\section{Introduktion til IFRS 3 og PPA}

Allokering af købesum er reguleret i IFRS 3 Business Combinations. Standarden blev implementeret i 2004 , mens en revideret udgave er trådt i kraft for regnskabsår, der begynder den 1. juli 2009 eller senere. Denne artikel tager udgangspunkt i den reviderede udgave, som dog i forhold til købesumsallokering kun indeholder mindre ændringer.

IFRS 3 omfatter de fleste overtagelser, dog er en række transaktioner ikke omfattet såsom joint ventures, transaktioner mellem selskaber, der er under samme parts kontrol, og gensidige selskaber.

Standarden indeholder retningslinjer for følgende emner:

- Identifikation af køber

- Fastlæggelse af overtagelsesdagen

- Identifikation og indregning af immaterielle aktiver

- Indregning af eventualforpligtelser

- Grænser for indregning af restruktureringshensættelser

- Amortisering af goodwill (ikke tilladt)

- Indregning af indtægt ved højere værdi af aktiverne end den betalte købesum

IFRS 3 skal ses i sammenhæng med IAS 36 Impairment of Assets samt IAS 38 Intangible Assets, da emneområderne er nært forbundne. Vi vil i denne artikel primært fokusere på identifikation og indregning af immaterielle aktiver overtaget i forbindelse med en virksomhedsovertagelse.

PPA er også relevant for virksomheder, der aflægger årsrapport efter årsregnskabsloven, idet $\AA$ RL $\S 122$ kræver, at identificerbare aktiver og forpligtelser i den overtagne virksomhed indregnes til dagsværdi på overtagelsestidspunktet, uanset om aktiverne eller forpligtelserne var indregnet i virksomhedens balance før overtagelsen. Der er visse forskelle mellem ÅRL og IFRS i relation til hvilke krav, der skal være opfyldt for at aktiver og forpligtelser kan indregnes i overtagelsesbalancen, men principperne er de samme. 


\section{1 "Overtagelsesmetoden"}

Kerneområdet i IFRS 3 er "Overtagelsesmetoden", hvilket er den metode, der skal anvendes på alle transaktioner omfattet af IFRS 3. Metoden anskuer transaktionen som købers erhvervelse af nettodriftsaktiverne i den overtagne virksomhed og behandler indregning og måling af aktiver og forpligtelser (inkl. eventualforpligtelser) overtaget ved købet. Denne indregning inkluderer også aktiver og forpligtelser, der ikke tidligere har været indregnet i regnskaberne for den overtagne virksomhed. Til gengæld er købers allerede erhvervede aktiver og forpligtelser på overtagelsestidspunktet ikke omfattet af transaktionen, hvorfor de indregnes som hidtil.

Selv om "Overtagelsesmetoden" omhandler alle overtagne aktiver vil denne artikel alene fokusere på de immaterielle aktiver. Ved en fuld PPA værdiansætter man dog også materielle anlægsaktiver, finansielle anlægsaktiver, omsætningsaktiver samt visse forpligtelser, herunder eventualforpligtelser, til dagsværdi, men vi har valgt at indsnævre fokus til de immaterielle anlægsaktiver, og de udfordringer virksomhederne møder ved identifikation, indregning og måling af disse.

\subsection{Grundtanken i PPA}

De aktiver, som ikke tidligere har været identificeret, men som efterfølgende indregnes i købers regnskab i kraft af "Overtagelsesmetoden", vil oftest være immaterielle aktiver. En praksis, hvor man allokerer hele forskellen mellem købesummen og den bogførte værdi til goodwill, kan ikke accepteres. I stedet for skal man identificere og værdiansætte de enkelte aktiver til dagsværdi, som illustreret i figur 1.

Figur 1: Allokering af købesum

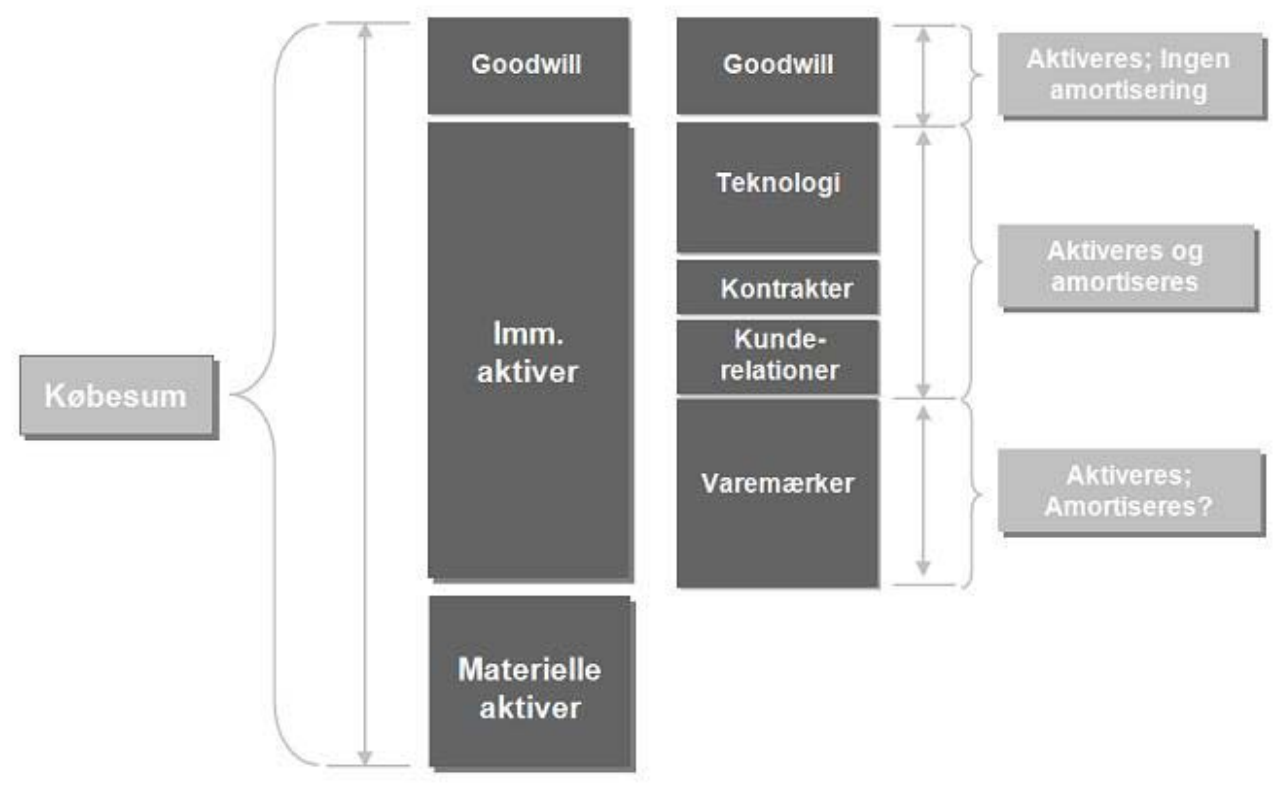

Som det også fremgår af figuren, skal aktiver med bestemmelig levetid amortiseres over deres forventede restlevetid. Immaterielle aktiver med ubestemmelig levetid skal ikke amortiseres, men årligt testes for et eventuelt nedskrivningsbehov. Goodwill er eksempel på et immaterielt aktiv med en ubestemmelig levetid. Varemærker kan være et andet eksempel. En naturlig konsekvens af kravet om udskillelse og særskilt indregning af overtagne immaterielle aktiver er, at goodwillbeløbet bør udgøre en relativt mindre del af købesummen.

Grundtanken i PPA er dermed at reducere størrelsen af goodwill, der altid har været en uigennemskuelig post i regnskabet. I stedet skal regnskaberne i højere grad afspejle de aktiver, der reelt er overtaget ved transaktionen, hvilket kræver, at man får udført en PPA med identifikation af de relevante aktiver og indregning til dagsværdi. En naturlig konsekvens af de reglerne for PPA er en større transparens omkring 
virksomhedsakkvisitioner i regnskabet, hvilket alt andet lige forbedrer informationsværdien for regnskabsbrugerne.

\section{Identifikation og indregning af immaterielle aktiver}

Det første skridt ved udarbejdelse af en PPA er at identificere de immaterielle aktiver, der er overtaget ved transaktionen. En korrekt identifikation kræver, at man forholder sig til indregningskriterierne i IFRS 3 samt benytter en struktureret proces, så det sikres, at alle relevante immaterielle aktiver bliver identificeret.

\subsection{Indregningskriterier for immaterielle aktiver}

IFRS 3 refererer til IAS 38 vedrørende definitionen af immaterielle aktiver. Et immaterielt aktiv er således et ikke-monetært aktiv uden fysisk substans, som enten kan udskilles selvstændigt eller er resultatet af kontraktlige/juridiske rettigheder. Aktivet skal være under kontrol af den pågældende virksomhed, og der skal være fremtidige økonomiske fordele ved brug af aktivet. Indregningskriterierne er illustreret i figur 2.

Figur 2: Indregningskriterier for immaterielle aktiver

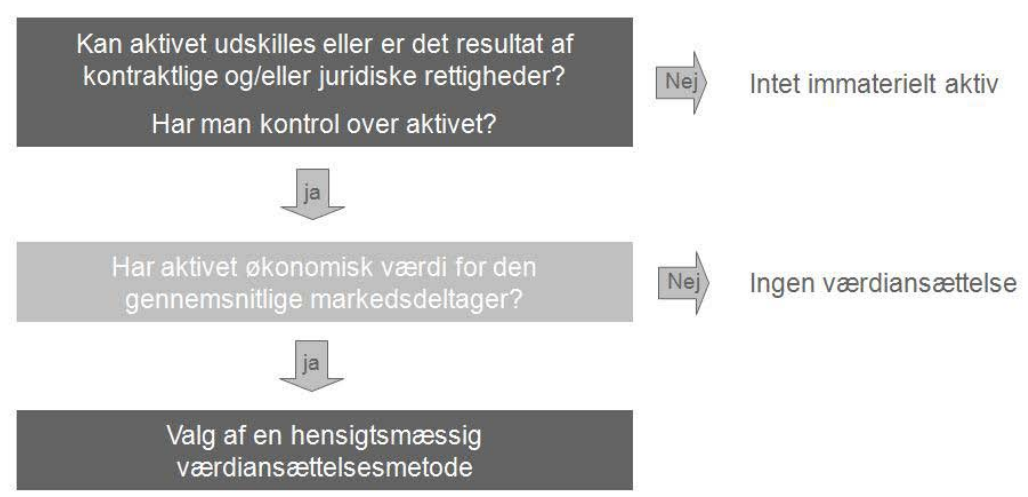

En stor del af arbejdet ved PPA er identifikation og vurdering af immaterielle aktiver. Hvis transaktionens primære drivkraft, som det meget ofte er tilfældet, er overtagelse af immaterielle aktiver, vil disse ofte have en betydelig værdi. Det vil typisk være varemærker, kundelister eller patenter. Herudover kan der være flere andre immaterielle aktiver, der har været af mindre betydning for transaktionens gennemførelse, men som skal identificeres og indregnes. Det kan eksempelvis være fordelagtige leasingaftaler. En oversigt over eksempler på immaterielle aktiver er vist i figur 3 .

\section{Figur 3: Eksempler på immaterielle aktiver}

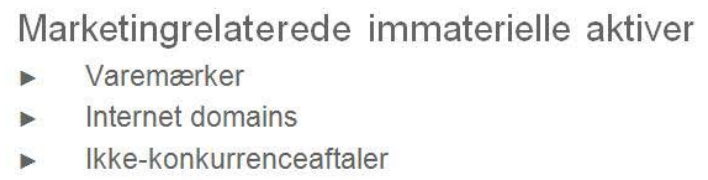

Kunderelaterede immaterielle aktiver

- Kundelister

- Indgåede ordre eller produktion

- Kundekontrakter

- Kunderelationer

\author{
Kontraktbaserede immaterielle aktiver \\ - Licenser og royaltykontrakter \\ - Leasingaftaler \\ - Senderettigheder
}

Teknologibaserede immaterielle aktiver
Patenteret og upatenteret teknologi
Software
- Hetabaser

Det er endvidere ofte en udfordring at skelne mellem immaterielle aktiver samt at definere, hvorvidt der er tale om et eller flere aktiver. Et eksempel er overtagelsen af et varemærke. Varemærket er ikke 
nødvendigvis det eneste aktiv, der fastholder en given omsætning af det pågældende produkt. Der kan også være tale om kunderelationer og kundelister. I denne situation er spørgsmålet, om man står overfor et immaterielt aktiv i form af varemærket, eller der reelt er tale om flere immaterielle aktiver, dvs. varemærke, kunderelationer og kundelister. I det følgende vil vi uddybe identifikationsprocessen af de immaterielle aktiver.

\subsection{Identifikationsproces}

Når de immaterielle aktiver skal identificeres, er det vigtigt at have en struktureret proces, så identifikationen er grundig og effektiv. I figur 4 nedenfor er opstillet et eksempel på en identifikationsproces. Indledningsvis bør virksomheden vurdere rationalet bagved transaktionen. Hvis de medarbejdere, der udfører købesumsallokeringen, ikke selv har deltaget i transaktionen, kan skriftligt materiale som pressemeddelelser og avisartikler samt anden offentlig tilgængelig information give et hurtigt overblik over rationalet. Herudover eksisterer der typisk en række interne informationskilder i form af købskontrakter og due diligence rapporter, som skal vurderes, da disse kan give en indikation af de vigtigste immaterielle aktiver i transaktionen.

Efter bearbejdning af det skriftlige materiale vil det typisk være nødvendigt at interviewe nøglepersoner fra både den købende virksomhed og den opkøbte virksomhed. Man vil typisk koncentrere sig om de personer, der har varetaget transaktionen, og dermed besidder en dybere forståelse for rationalet bag.

Udover at drøfte rationalet for transaktionen, er det helt centralt samtidig at forholde sig til, hvilket rationale andre potentielle købere måtte have. Identifikation og værdiansættelse af immaterielle aktiver ved udførsel af en PPA skal nemlig tage udgangspunkt $\mathrm{i}$ den hypotetiske gennemsnitlige markedsdeltager og ikke den konkrete køber. Dette betyder, at man ikke alene skal forholde sig til sin egen virksomheds opfattelse af den tilkøbte virksomhed, men også inddrage betragtninger om den generelle opfattelse af virksomheden, og de aktiver den indeholder.

Figur 4: Identifikation af immaterielle aktiver

Overvej køber og sælgers motiver

Gennemse dokumentation

Information fra nøglepersoner

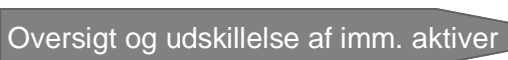

Fastlæg hierarkiet af imm. aktiver
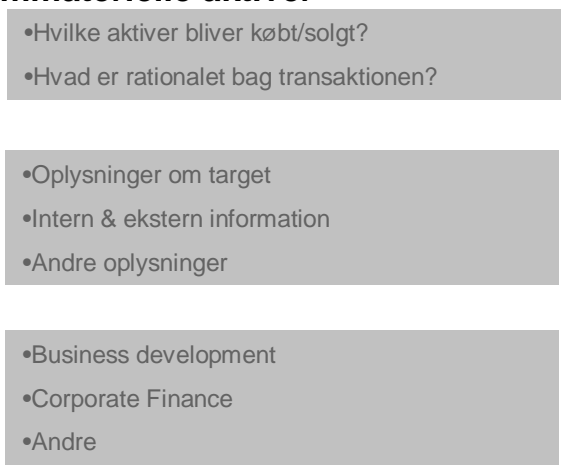

-Identifikation og udskillelse af alle immaterielle aktiver, der skal værdiansættes

•Fastlægge sammenhængen mellem

immaterielle aktiver

•Rangere aktiverne efter bidrag til omsætning

Som opsamling på identifikationen bør man udarbejde en oversigt, hvor samtlige immaterielle aktiver identificeres, og de aktiver, der opfylder indregningskriterierne udskilles til senere værdiansættelse og indregning i regnskabet. Til brug for den senere værdiansættelse af de immaterielle aktiver vil det være hensigtsmæssigt at fastlægge et hierarki af de immaterielle aktiver ordnet efter deres bidrag til den samlede omsætning. Dette sikrer en afklaring af de indbyrdes sammenhænge mellem de immaterielle aktiver, herunder hvilke aktiver, der bidrager mest til omsætningen og de forventede fremtidige pengestrømme. Alternativt kan aktiverne opdeles efter deres respektive bidrag til indtjeningen. En sådan opdeling kan være 
hensigtsmæssig i virksomheder, hvor enkelte aktiver i form af højere marginer bidrager forholdsmæssigt meget til den samlede indtjening i virksomheden.

Identifikationsprocessen er som beskrevet ovenfor omfattende og et af de vigtigste punkter i arbejdet med PPA. I denne proces får man forståelse for, hvilke aktiver der er overtaget, og køberen begynder at få en dybere indsigt i, hvilken virksomhed man reelt har købt. Identifikationen vil danne baggrund for den senere værdiansættelse og dermed den endelige allokering af købesummen til de enkelte aktiver.

\subsection{Goodwill}

Selv om man identificerer en række immaterielle aktiver, vil der i de fleste tilfælde fortsat være en betydelig merværdi til goodwill. Som følge af allokering til andre aktiver vil goodwill dog udgøre en relativ mindre del af købesummen end uden allokering.

Goodwill har altid været en uhåndgribelig størrelse, som kan være svær at forklare. Jævnfør teorien repræsenterer goodwill en virksomheds evne til at generere overnormal indtjening [Elling (2008)]. ' I praksis kan goodwill bestå af mange forskellige forhold og som eksempler kan nævnes:

- Værdi af arbejdsstyrke

- Geografisk tilstedeværelse

- Stærk positiv relation til medarbejderne

- God kreditrating og adgang til kapitalmarkederne

- Gode relationer til myndighederne

- $\quad$ Synergi

Sammensætningen af goodwill vil være forskellig på tværs af transaktioner, men fælles gælder det, at de skal bidrage til virksomhedens evne til at skabe fremtidige pengestrømme.

Ved udarbejdelse af allokeringen værdiansættes goodwill som residualen mellem øvrige aktiver og købesummen. Dette betyder også, at såfremt man har købt virksomheden til en værdi lavere end de revurderede aktiver, vil der opstå "negativ goodwill". I dette tilfælde indtægtsføres residualværdien efter en revurdering af om alle identificerbare aktiver, forpligtelser og eventualforpligtelser er identificeret og indregnet og om dagsværdierne er opgjort korrekt.

\section{Værdiansættelse af immaterielle aktiver}

De identificerede immaterielle aktiver, der opfylder indregningskriterierne, skal værdiansættes til dagsværdi. Dagsværdi er defineret som det beløb et aktiv kan omsættes til ved handel mellem kvalificerede, villige og indbyrdes uafhængige parter. Denne værdi tager ikke hensyn til købers specifikke synergieffekter, men definerer dagsværdi i forhold til den gennemsnitlige markedsdeltager. Dette betyder, at værdiansættelsen tager udgangspunkt i markedsdeltagernes og ikke den aktuelle købers anvendelse af det pågældende aktiv. Derfor skal et immaterielt aktiv identificeres og indregnes upåagtet, at køberen ikke ønsker at gøre brug af aktivet. Ønsker køberen ikke at anvende aktivet, eller skønnes levetiden at være kort, indregner man det i åbningsbalancen, hvorefter køberen afskriver værdien over en kort periode eller foretager en nedskrivningstest af aktivet og eventuelt nedskriver det til nul. Et eksempel på dette kunne være et varemærke, der er overtaget ved transaktionen, men som ikke passer ind i køberens portefølje og derfor afvikles.

\subsection{Overordnede værdiansættelsesmetoder}

Der er tre overordnede metoder til at fastslå dagsværdien. Det er henholdsvis markeds-, indtjenings- og omkostningsmetoden.i Metoderne skal prioriteres i nævnte rækkefølge.

Noterede markedspriser fra aktive markeder vil give den mest præcise værdiansættelse af et immaterielt aktiv. Det er imidlertid undtagelsen, at der forefindes et aktivt marked for det aktuelle immaterielle aktiv.. 
Alternativt kan man finde sammenlignelige transaktioner, men det vil kun være i ganske få tilfælde, at disse er tilgængelige.

Figur 5: Hierarki for værdansættelsesmetoder

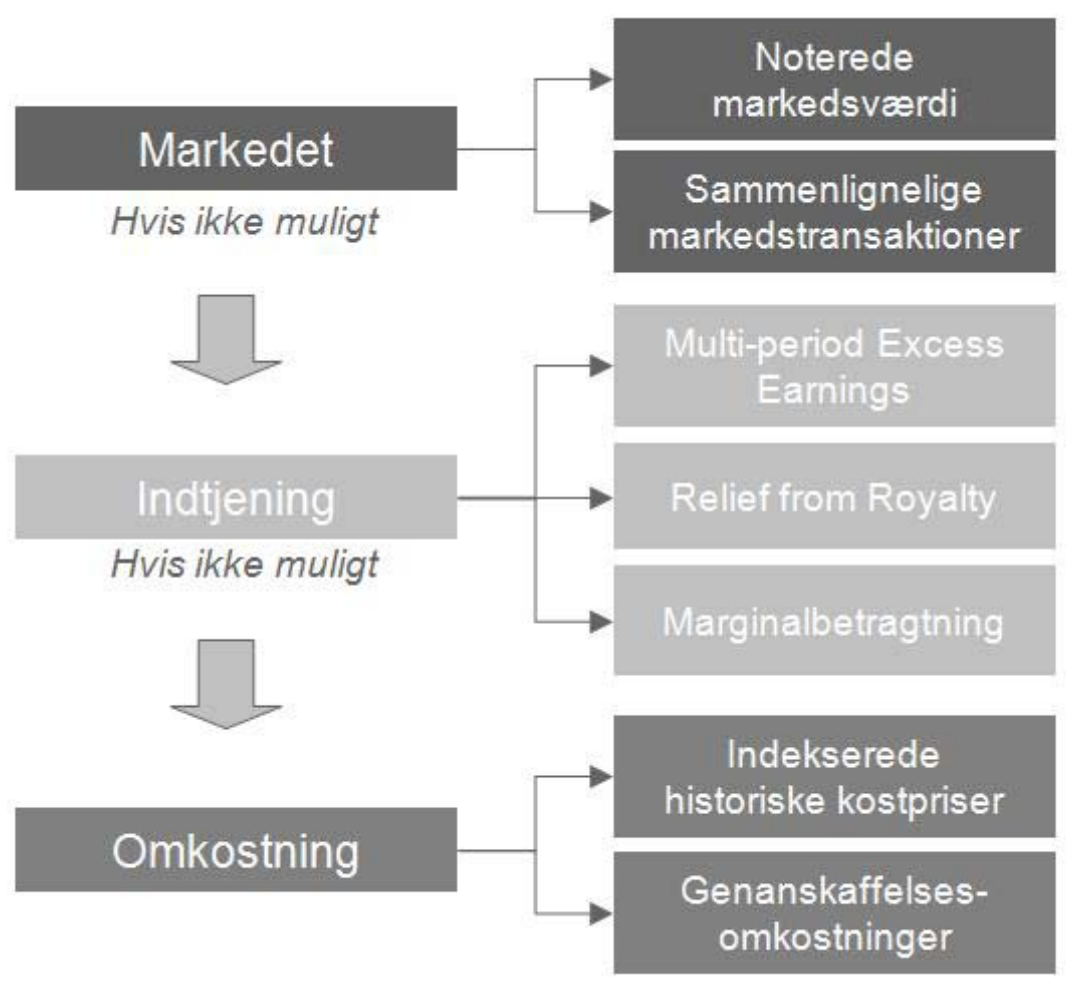

Derfor er langt de fleste værdiansættelser af immaterielle aktiver baseret på indtjening, og er dermed opstilling af en variant af discounted cash flow-model (DCF-model). En DCF-model til brug for værdiansættelse af immaterielle aktiver er på afgørende områder forskellig fra en traditionel værdiansættelse, da det ofte kræver en række indledende beregninger, før man har isoleret den del af indtjeningen, der vedrører det pågældende immaterielle aktiv. I de følgende afsnit vil vi gennemgå de to hyppigst anvendte indtjeningsbaserede metoder, henholdsvis Multi-period Excess Earnings og Relief from Royalty.

\subsubsection{Multi-period Excess Earnings}

Multi-period Excess Earnings-metoden (MEEM) anvendes primært til værdiansættelse af hovedaktivet. Metoden forudsætter, at man har værdiansat alle øvrige aktiver, da bestemmelse af værdien af hovedaktivet tager udgangspunkt i den indtjening, der er tilbage efter fradrag af kapitalomkostninger til øvrige aktiver (Excess Earnings). Når man udfører en PPA kan man som udgangspunkt kun værdiansætte et enkelt aktiv med MEEM. Metoden er illustreret i figur 6, hvor aktivet, der værdiansættes, er kunderelationer. 
Figur 6 Multi-periode Excess Earnings-metoden (MEEM)

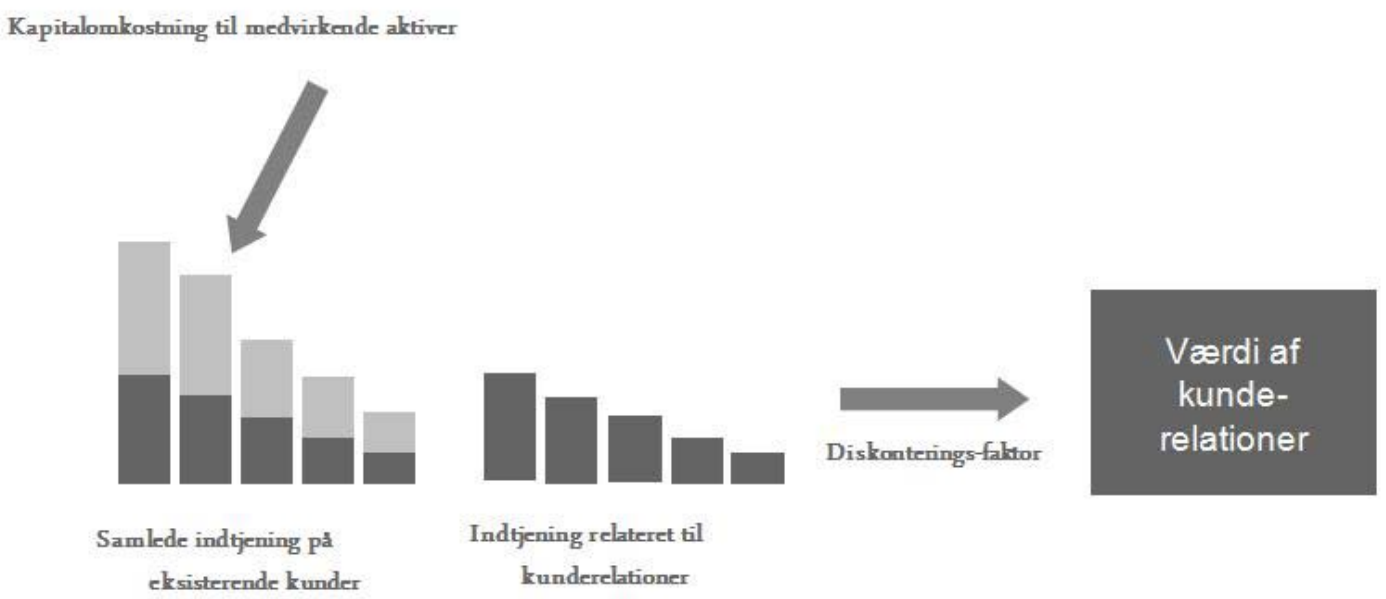

Som illustreret i figuren vil indtjeningen være aftagende, da kunderelationerne til de eksisterende kunder (på overtagelsestidspunktet) vil ophøre over tid. Kunderelationerne har derfor en bestemmelig levetid. MEEM er i praksis en anvendelig værdiansættelsesmetode, når man har identificeret og værdiansat alle øvrige aktiver.

Ved identifikation af kunderelaterede aktiver er det vigtigt at skelne mellem forskellige typer af immaterielle aktiver. Har man f.eks. en kundegruppe, der er omfattet af kontrakter, mens en anden kundegruppe alene vender tilbage pga. relationer uden kontraktlige forpligtelser, så vil man kunne identificere to immaterielle aktiver: Kundekontrakter samt kunderelationer i tilfælde hvor flere kundegrupper er identificeret, må virksomhedens samlede omsætning opsplittes på hver enkelt kundegruppe, såfremt MEEM-metoden ønskes benyttet til at værdiansætte de enkelte kundegrupper. Dette kan ligeledes være tilfældet i situationer, hvor en del af virksomhedens omsætning stammer fra salg foretaget gennem distributionsnetværk. I dette scenarie skal det ligeledes bestemmes, hvorvidt distributionsnetværket er kvalificeret som et selvstændigt aktiv i henhold til IAS 38. Regnskabsreglerne er ikke klare på dette område, men praksis vil mene, at distributionsnetværket skal medtages i det tilfælde, at størstedelen af værdiskabelsen foretages af virksomheden, og hvor distributionsnetværkets opgave mere eller mindre består af at flytte varer fra virksomheden til slutbruger. Foregår salget og kontakten til slutbrugeren imidlertid i distributionsleddet og har virksomheden som følge heraf ikke kontrol med distributionsleddet, bør dette ikke indregnes som et særskilt aktiv.

\subsubsection{Relief from Royalty}

Relief from Royalty-metoden er hyppigt anvendt til værdiansættelse af f.eks. varemærker. Metoden tager udgangspunkt i, at man ved hjælp af en markedskonform royaltysats bestemmer den del af indtjeningen, der relaterer sig til varemærket. Værdien af varemærket kan efterfølgende bestemmes ved diskonteringen af den fremtidige indtjening med en passende diskonteringsfaktor. 
Figur 7: Relief from royalty-metoden

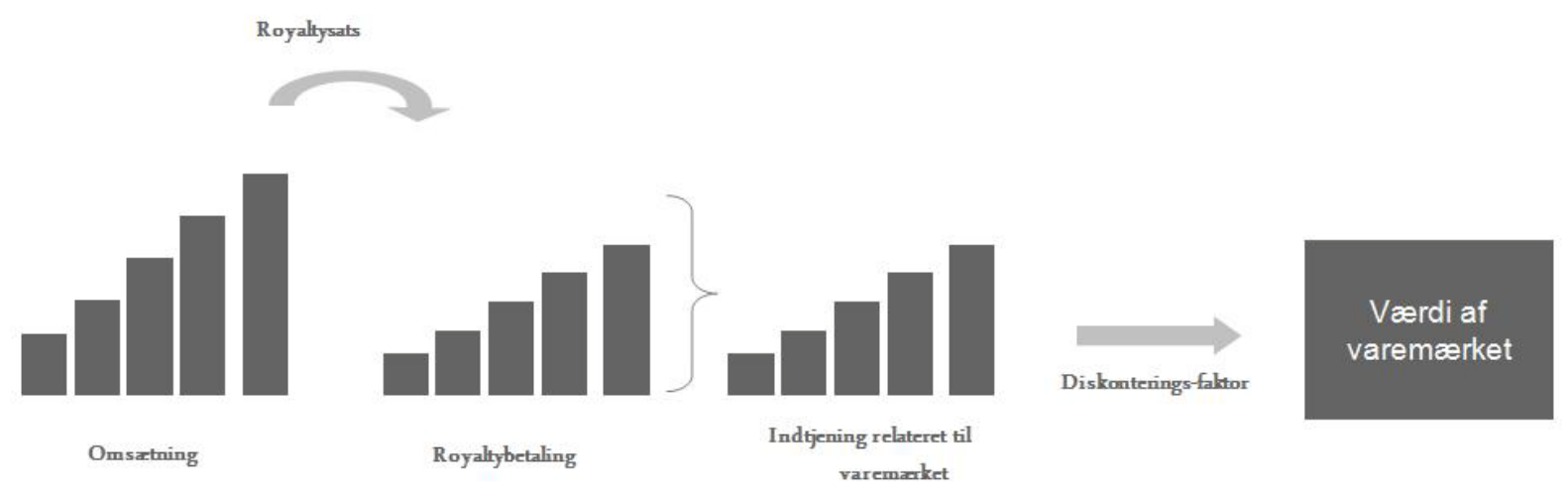

Det kan i nogle tilfælde være en betydelig udfordring at bestemme royaltysatsen. Størrelsen på royaltysatsen vil afhænge af styrken af varemærket. Stærke varemærker, der kan fastholde en relativt høj indtjeningsmargin, vil typisk have en relativt højere royaltysats. Ved bestemmelse af royaltysatsen vil man eksempelvis kigge på indgåede royaltyaftaler eller royaltyaftaler med sammenlignelige varemærker, hvorved man kan bestemme et niveau for royaltysatsen. Efterfølgende må man dog efterprøve denne royaltysats med nærmere analyser af virksomhedens indtjening, herunder karakteristika på det pågældende marked. Samtidig skal man tage stilling til, om varemærket har ubestemmelig levetid eller om styrken i varemærket aftager over tid, så det efter en årrække ikke bidrager til omsætningen.

\subsubsection{Omkostningsmetoden}

Omkostningsmetoden værdiansætter et aktiv ud fra genanskaffelsesprisen eller de udviklingsomkostninger, der er benyttet på det pågæIdende aktiv. Metoden benyttes ofte til at værdiansætte aktiver, hvortil der ikke kan allokeres cash flows. Dette kan eksempelvis være internt udviklet software. Genanskaffelsesprisen er en estimering af de omkostninger, det ville kræve at opbygge et identisk immaterielt anlægsaktiv. For at genanskaffelsesprisen kan benyttes, kræves det, at det opbyggede immaterielle anlægsaktiv har samme anvendelsesområde og karakteristika som det oprindelige.

Udviklingsomkostningerne benyttet på det pågældende aktiv kan ligeledes benyttes til at værdiansætte det immaterielle anlægsaktiv, da det her antages, at disse omkostninger afspejler dagsværdien af aktivet.

Omkostningsmetoden bør benyttes med forsigtighed, idet de omkostninger, der historisk er brugt til at opbygge det immaterielle anlægsaktiv, ikke nødvendigvis er et eksakt estimat for det immaterielle anlægsaktivs fremtidige værdi.

\subsection{Tax Amortisation Benefit}

Ifølge dansk lovgivning tillades erhvervede aktiver afskrevet skattemæssigt. Disse skattemæssige afskrivninger medfører en sparet skattebetaling for virksomheden i de år, hvor afskrivningerne foretages, hvilket har en værdi for virksomheden. Tax amortisation benefit (TAB) udgør nutidsværdien af denne skattefordel. Idet en potentiel køber af et aktiv vil have skattemæssige overvejelser inde i købsbeslutningen, vil køberen være villig til at betale for de skattemæssige fordele, der opnås ved køb af aktivet. TAB bør 
derfor inkluderes, når dagsværdien af et aktiv skal opgøres ved hjælp af den indtjeningsbaserede metode eller omkostningsmetoden. Ved anvendelse af markedsmetoden er TAB allerede inkluderet i de multipler, som værdien estimeres på baggrund af, og er dermed allerede inkluderet i den estimerede dagsværdi.

\subsection{Bestemmelse af resterende levetid}

Uanset valg af metode er det nødvendigt, at forholde sig til den resterende levetid for det enkelte immaterielle aktiv. Det er en central del af PPA-processen at bestemme den resterende levetid på de immaterielle aktiver, da det har ganske stor indflydelse på den fremtidige regnskabsaflæggelse og værdiansættelsen, såfremt en indtjeningsbaseret metode anvendes. Overordnet set skelner man mellem immaterielle aktiver med bestemmelig levetid og aktiver med ubestemmelig levetid

Immaterielle aktiver med bestemmelig levetid vil blive indregnet i balancen og amortiseret over den resterende levetid. Amortiseringen har direkte indflydelse på den årlige indtjening og Earnings per Share (EPS) indtil aktivet er fuldt amortiseret.

Immaterielle aktiver med ubestemmelig levetid vil også blive indregnet i balancen, men bliver ikke amortiseret. I stedet bliver disse immaterielle aktiver nedskrivningstestet årligt. Der kommer dermed ingen effekt på indtjening og EPS, medmindre der indtræffer et nedskrivningsbehov ved den årlige nedskrivningstest. Immaterielle aktiver med ubestemmelig levetid, kan dermed give en mere volatil indtjening.

Det er således af stor betydning, hvilken levetid de enkelte aktiver har. Levetiden af et immaterielt aktiv skal defineres ud fra den periode, hvor det forventes, at aktivet direkte eller indirekte vil bidrage til virksomhedens indtjening. Hvis levetiden ikke kan bestemmes præcist, bør aktivet amortiseres over den mest sandsynlige levetid.

\subsection{Afstemning af købesumsallokeringen}

Efter at have værdiansat de enkelte aktiver er det nødvendigt at afstemme hele købesumsallokeringen. En afstemning skal sikre, at de enkelte værdiansættelser hænger sammen internt, og at der ikke er inkonsistens eller svagheder ved antagelser og forudsætninger.

En PPA er ikke færdig før afstemningen er lavet. Derfor skal afstemningen have samme fokus som værdiansættelsen af de enkelte immaterielle aktiver.

\subsubsection{Kvalitativ afstemning}

Ved den kvalitative afstemning bør man kaste et kritisk blik på de værdier, man har bestemt for de enkelte immaterielle aktiver. Man bør vurdere følgende forhold:

- Summen af immaterielle aktiver relativt til købesummen

- Værdien af de enkelte immaterielle aktiver relativt til hinanden

- De enkelte immaterielle aktiver relativt til købesummen (herunder sammenhæng med rationalet for transaktionen)

- Værdien af de immaterielle aktiver og goodwill relativt til industrigennemsnit

Denne vurdering skal afdække inkonsistens i allokeringen. Efter at have opnået forståelse for aktiviteterne i den opkøbte virksomhed samt rationalet for transaktionen, bør der være en ren intuitiv sammenhæng mellem de enkelte immaterielle aktivers værdi. Er dette ikke tilfældet, skal metoder, antagelser og forudsætninger vurderes og nødvendige justeringer foretages. 
Antagelser og forudsætninger bør endvidere sammenlignes på tværs af de enkelte værdiansættelser, så det sikres, at modstridende argumenter ikke benyttes.

\subsubsection{WACC-WARA afstemning}

Udover den kvalitative afstemning indeholder en veludført allokering også en ren kvantitativ afstemning. En sådan afstemning foretager man ofte ved sammenligning af weighted average cost of capital (WACC) med weighted average return on assets (WARA). Metoden bliver kaldt for WACC-WARA-metoden. Denne metode kontrollerer, at der er sammenhæng mellem den diskonteringssats (WARA), der anvendes på de enkelte aktiver og selskabets WACC. Et eksempel på dette er vist i figur 8.

Figur 8: Eksempel på afstemning med WACC-WARA

\begin{tabular}{|c|c|c|c|}
\hline Aktiver & Dagsværdi & $\begin{array}{l}\text { diskonterings- } \\
\text { faktor }\end{array}$ & Vægtet afkast \\
\hline Nettoarbejdskapital & 900 & $3 \%$ & $0,2 \%$ \\
\hline Materielle anlægsaktiver & 8.000 & $5 \%$ & $2,4 \%$ \\
\hline Varemærker & 1.500 & $12 \%$ & $1,1 \%$ \\
\hline Kunderelationer & 1.300 & $12 \%$ & $1,0 \%$ \\
\hline Goodwill & 4.700 & $15 \%$ & $4,3 \%$ \\
\hline Weighted Average Return on Assets (WARA) & 16.400 & & $9,0 \%$ \\
\hline Weighted Average Cost of capital (WACC) & & & $9,0 \%$ \\
\hline
\end{tabular}

WARA er det vægtede afkast på de enkelte aktiver, dvs. nettoarbejdskapital, materielle og immaterielle aktiver, herunder goodwill. Vægtene i beregningen er aktivets dagsværdi i forhold til den totale dagsværdi. For at købesumsallokeringen hænger sammen, skal det vægtede afkast på aktiverne WARA være identisk med det vægtede afkastkrav WACC for virksomheden. Er der betydelig forskel hænger allokeringen ikke sammen, hvorfor man må tilbage og vurdere værdiansættelsen af de enkelte immaterielle aktiver, indtil der er overensstemmelse i afstemningen. Først når dette er tilfældet, har man afsluttet allokeringen.

TAB har imidlertid det paradoks, at jo højere købesummen er for det enkelte aktiv, jo højere bliver de skattemæssige afskrivninger og dermed værdien af de fremtidige skattemæssige besparelser. En stigning i disse skattemæssige besparelser medfører ligeledes en stigning i værdien af aktivet for køberen. Der er derfor cirkularitet i beregningen af TAB, hvilket man bør være opmærksom på, ved værdiansættelse af aktiver.

\section{$5 \quad$ Regnskabsmæssige konsekvenser ved PPA}

PPA har direkte indflydelse på den fremtidige regnskabsaflæggelse, hvorfor det er overordentligt vigtigt, at der foretages en retvisende allokering. Vi vil i de følgende afsnit kort berøre påvirkning af købers årsregnskab.

\subsection{Påvirkning af købers årsregnskab}

Allokeringen af købesummen har stor indflydelse på købers fremtidige årsregnskab. En ukorrekt allokering skaber støj i indtjeningsbilledet, idet der opstår en risiko for fejl i den initiale værdiansættelse af det enkelte aktiv, hvilket kan resultere i fremtidige nedskrivninger, som ikke er begrundet i udviklingen af aktivets dagsværdi men er af mere procesteknisk karakter. Derfor bør der foretages en grundig og så retvisende PPA som muligt.

En af de væsentligste konsekvenser ved en købesumsallokering er identificering og indregning af immaterielle aktiver, der ikke tidligere har været balanceført. En køber vil i de fleste tilfælde være vidende om aktivernes eksistens, og disse er ofte drivkraften i transaktionen, men aktiverne er normalt ikke indregnet $\mathrm{i}$ sælgers regnskab eller er indregnet til relativt lave værdier, såfremt aktiverne er internt oparbejdet.

I figur 9 er opstillet et illustrativt eksempel, der viser de regnskabsmæssige konsekvenser ved et opkøb og efterfølgende identifikation af immaterielle anlægsaktiver. Det har væsentlig betydning for den fremtidige 
regnskabsaflæggelse, hvilke immaterielle aktiver der identificeres, herunder hvilken værdi, som indregnes samt deres resterende levetid. Amortiseringerne vil indgå i den fremtidige resultatopgørelse og påvirke EPS.

Figur 9: Eksempel på påvirkning af købers årsregnskab

\begin{tabular}{|c|c|c|c|c|}
\hline Balance & $\begin{array}{l}\text { Bogført værdi før } \\
\text { transaktion }\end{array}$ & $\begin{array}{l}\text { Dagsværdi (Tilgang } \\
\text { til købers balance) }\end{array}$ & $\begin{array}{l}\text { Resterende } \\
\text { levetid }\end{array}$ & $\begin{array}{c}\text { Årlig } \\
\text { amortisering }\end{array}$ \\
\hline \multicolumn{5}{|l|}{ Materielle anlægskativer } \\
\hline Varedebitorer & 7,500 & 7,500 & & \\
\hline Lager & 15,100 & 15,100 & & \\
\hline Materielle anlægsativer & 50,000 & 50,000 & & \\
\hline 1 alt & 72,600 & 72,600 & & \\
\hline \multicolumn{5}{|l|}{ Immaterielle anlægsaktiver } \\
\hline Varemærker & Ikke tidligere identificeret & 80,000 & Ubestemmelig & \\
\hline Teknologi & Ikke tidligere identificeret & 20,000 & 10 & 2,000 \\
\hline Kundelister & Ikke tidligere identificeret & 80,000 & 8 & 10,000 \\
\hline$I$ alt & & 180,000 & & 12,000 \\
\hline Goodwill & Ikke tidligere identificeret & 200,000 & & \\
\hline $\mathrm{Ialt}$ & & 200,000 & & \\
\hline Købesum & & 452,600 & & \\
\hline Resultatopgørelse & $\begin{array}{l}\text { Før transaktion } \\
\qquad A r-1\end{array}$ & $\begin{array}{l}\text { Efter transaktion } \\
\qquad \text { Ar } 1\end{array}$ & Ar 2 & Ar 3 \\
\hline EBITDA & 70,000 & 72,000 & 74,000 & 76,000 \\
\hline Restruktureringsomkostninger & & $-10,000$ & & \\
\hline Afskrivninger (mat. anlægsaktiver) & $-5,000$ & $-5,000$ & $-5,000$ & $-5,000$ \\
\hline Amortiseringer (immat. anlægsaktiver) & & $-12,000$ & $-12,000$ & $-12,000$ \\
\hline Nedskrivninger & & (?) & (?) & (?) \\
\hline I alt & $-5,000$ & $-17,000$ & $-17,000$ & $-17,000$ \\
\hline EBIT & 65,000 & 45,000 & 57,000 & 59,000 \\
\hline
\end{tabular}

Identificerer man immaterielle aktiver med ubestemmelig levetid, vil man årligt skulle udføre en nedskrivningstest på disse aktiver. Løbende vil disse aktiver ikke belaste resultatopgørelsen med amortiseringer, men ved ændrede fremtidsudsigter kan det til gengæld medføre en betydelig nedskrivning, da nedskrivningstesten vil indikere et nedskrivningsbehov. Derfor kan immaterielle aktiver med ubestemmelig levetid give en mere volatil indtjening frem for aktiver med bestemmelig levetid.

\section{Ekstern rapportering}

Ifølge IFRS 3 er det tilstrækkeligt at rapportere identificerede immaterielle aktiver erhvervet ved en virksomhedstranaktion (business combination) under én samlet post. Imidlertid virker det paradoksalt, at standarden foreskriver virksomhederne at foretage komplekse interne beregninger samt identifikation og allokeringer til flere immaterielle aktiver, når virksomhederne kan nøjes med en relativ lav specifikationsgrad $\mathrm{i}$ den eksterne rapportering. I langt de fleste tilfælde indeholder den eksterne rapportering kun en relativ lav specifikationsgrad. Inden virksomheden vælger kun at følge minimumsspecifikationsreglerne bør flere faktorer overvejes.

Hovedelementet vil typisk være en afvejning af at give markedet den nødvendige information, men samtidigt ikke offentliggøre informationer, der kan være konkurrencefølsomme. Udfaldet af denne afvejning vil være forskelligt fra case til case, men generelt er det vores holdning, at mange virksomheder kan specificere deres købesumsallokering yderligere uden at frigive konkurrencefølsomme informationer. Virksomheden kan nøjes med at angive dagsværdien (fair value) for de enkelte aktiver uden at offentliggøre bagvedliggende budgetter, antagelser og strategier. Idet virksomhederne i de interne beregninger allerede har foretaget detaljerede beregninger, vil en større detaljeringsgrad i afrapporteringen ikke øge ressourcebehovet hos virksomheden. Derimod kan virksomheden opnå en højere troværdighed i markedet, idet analytikere og investorer får bedre mulighed for at analysere de enkelte transaktioner.

For at illustrere de faktiske udfordringer ved købesumsallokeringen har vi taget udgangspunkt i en faktisk eksternt rapporteret købesumsallokering foretaget på en dansk virksomheds opkøb. Vi tager her udgangspunkt i et eksempel, hvor den eksterne rapportering er detaljeret uden at virksomheden offentliggør konkurrencefølsomme oplysninger. 


\subsection{Dako A/S}

Kapitalfonden EQT overtog den 1. marts 2007 diagnostikselskabet Dako A/S. Dako A/S er ikke børsnoteret, men EQT har valgt at følge de internationale regnskabsstandarder. Købesumsallokeringen er derfor udarbejdet efter retningslinjerne i IFRS 3.

Dako viser eksplicit, hvilke immaterielle aktiver, der er identificeret samt værdien af disse. Tabellen i figur 10 er hentet fra Dakos årsrapport for 2007.

Figur 10: Dako A/S: Købesumsallokering

\begin{tabular}{|c|c|c|c|c|c|c|c|}
\hline DKK Thousand & Goodwill & Brands & Know-how & $\begin{array}{l}\text { Customer } \\
\text { contracts }\end{array}$ & $\begin{array}{r}\text { Completed IT } \\
\text { devel. Projects }\end{array}$ & $\begin{array}{r}\text { Patents, } \\
\text { licenses and } \\
\text { similar rights }\end{array}$ & Total \\
\hline \multicolumn{8}{|l|}{2007} \\
\hline $\begin{array}{l}\text { Acquired through business } \\
\text { combinations }\end{array}$ & 3.229 .884 & 1.121 .000 & 390.000 & 2.334 .000 & 89.489 & 208.570 & 7.372 .943 \\
\hline Additions during the year & & & & & & 5.561 & 5.561 \\
\hline Disposals during the year & & & & & & (585) & (585) \\
\hline & & & & & $(4.302)$ & (1.765) & $(6.067)$ \\
\hline \multicolumn{8}{|c|}{ Transferred to assets held for sale } \\
\hline Exchange rate adjustments & & & & & & $(2.048)$ & $(2.048)$ \\
\hline Cost at December 31 & 3.229 .884 & 1.121 .000 & 390.000 & 2.334 .000 & 85.187 & 209.733 & 7.369 .804 \\
\hline
\end{tabular}

Det fremgår klart af rapporten, hvilke immaterielle aktiver der er identificeret. Ligeledes fremgår værdien af de enkelte immaterielle aktiver også eksplicit, og antagelser omkring levetiden for de enkelte aktiver er beskrevet efterfølgende. Denne rapportering giver regnskabslæser mulighed for at analysere transaktionen. Læseren kan derfor bedre vurdere, hvad opkøbet af Dako har omfattet, og hvordan købesummen fordeler sig på de forskellige typer aktiver.

Ligeledes opgører DAKO den efterfølgende regnskabsmæssige behandling, og ændringerne i de enkelte aktivers værdier kan klart følges af regnskabslæser fra år til år. I figur 11 nedenfor er den efterfølgende rapportering fra DAKOs årsrapport 2008 vist

Figur 11: Dako A/S: Rapportering

\begin{tabular}{|c|c|c|c|c|c|c|c|}
\hline DKK Thousand & Goodwill & Brands & Know-how & $\begin{array}{l}\text { Customer } \\
\text { contracts }\end{array}$ & $\begin{array}{r}\text { Other } \\
\text { intangibles } \\
\end{array}$ & $\begin{array}{r}\text { Development } \\
\text { costs }\end{array}$ & Total \\
\hline Cost at January 1, 2008 & 3.229 .884 & 1.121 .000 & 390.000 & 2.334 .000 & 294.920 & & 7.369 .804 \\
\hline $\begin{array}{l}\text { Acquired through business } \\
\text { combinations }\end{array}$ & & & & & 4.644 & & 4.644 \\
\hline Additions during the year & 109.585 & & & & 14.774 & 4.164 & 128.523 \\
\hline Disposals during the year & $(4.974)$ & & & & (20) & & $(4.994)$ \\
\hline Exchange rate adjustments & (19.799) & & & & (648) & & $(20.447)$ \\
\hline Cost at December 31 & 3.314 .696 & 1.121 .000 & 390.000 & 2.334 .000 & 313.670 & 4.164 & 7.477 .530 \\
\hline
\end{tabular}

Kilde: Dako A/S årsrapport 2008, s. 30

På denne baggrund bliver transaktionen mere gennemskuelig for regnskabslæsere. Eksempelvis bliver regnskabslæsere bedre i stand til at forstå den påtagne risiko. Risikoen afhænger blandt andet af, hvilke aktiver der er overtaget, eftersom at immaterielle aktiver så som patenter, licenser, varemærker m.m. typisk har en lavere risiko end goodwill. Endvidere vil en udskillelse af købesummen i enkeltaktiver som alternativ til goodwill give en større forståelse for den fremtidige indtjeningsstrøm. Eksempelvis vil patenter give regnskabslæseren en vis sikkerhed for indtjeningen i den periode patentet løber. Opsummerende viser ovenstående købesumsallokering, at det er muligt at rapportere identificerede immaterielle aktiver i 
årsrapporten uden at offentliggøre konkurrencefølsomme oplysninger og samtidig forbedre informationsværdien i regnskabet.

\section{Konklusion}

Vi har i denne artikel redegjort for indholdet i en veludført PPA. Arbejdet med købesumsallokering er en relativt kompliceret øvelse, der kræver en grundig identifikationsproces samt kendskab til de enkelte værdiansættelsesmetoder. Idet allokeringen, herunder bestemmelse af aktivernes levetid, har indflydelse på den fremtidige regnskabsaflæggelse, er det vigtigt at lave en grundig og korrekt købesumsallokering. Ved aflæggelse af årsregnskab vælger langt de fleste virksomheder en lav specifikationsgrad. Vi mener, at virksomhederne i mange tilfælde kunne øge specifikationsgraden uden at afsløre konkurrencefølsomme oplysninger.

Vores erfaring med PPA viser også, at PPA for mange fremstår som enten noget ukendt eller en meget ressourcekrævende proces, der ikke skaber værdi. Vi mener dog, at en korrekt udført PPA kan skabe betydelig værdi, hvis man starter PPA-processen allerede under transaktionen og benytter PPA aktivt. Den lovmæssige regulering har fastlagt, at man skal foretage PPA ved virksomhedsovertagelser. Hvis man imidlertid formår at benytte PPA som et strategisk værktøj, vil man kunne drage fordel af den proces og de ressourcer, man investerer $\mathrm{i}$ allokeringen. I vores virke som rådgivere oplever vi relativt sjældent, at virksomhederne har en proaktiv tilgang til PPA på trods af de helt klare fordele. Dette tema vil blive adresseret i en efterfølgende artikel.

\footnotetext{
i Jens O Elling (2008). "Finansiel rapportering - teori og regulering", Forlaget Gjellerup.

"De tre metoder er beskrevet i "International Valuation Guidance Note No. 4 - Valuation of Intangible Assets", The International Valuation Standards Committee (IVSC). For yderligere information henvises til Financial Accounting Standards (FAS) 157, hvilket er de amerikanske regnskabsregler, som IFRS 3 er udarbejdet på baggrund af.
} 